\title{
23 北海道において畜産污水を発生源とするハナアブ類について
}

○佐々木 均・三上暁子（酪農大·昆虫）

Droneflies occurring from effluent of manure in Hokkaido (Diptera: Syrphidae)

Sasaki, H., Mikami, A.

たい肥場などに溜まる「れき汁」など畜産污水を発生源とするハナアブ類の種類を特定し 各発育ステージごとの形態学的特徵を把握して検索を容易にする目的でオビトラップ法を用 いた調査を行い, シマハナアブ, キタシマハナアブ, ナミハナアブ, ホシメハナアブ, アシ ブトハナアブの 3 属 5 種を発生種として特定した。そこで, それぞれの種を室内で飼育して 得られた各発育ステージごとの標本を双眼実体顕微鏡と走査型電子顕微鏡で精査したところ, 卵ではアシブトハナアブが卵款のユニットの形態によって，終龄幼虫ではアシブトハナアブ が背面から透視される気管の形状によって，ホシメハナアブが第 7 擬脚の前方に位置する棘 列の存在によってそれぞれ他の種から区別された。蛹では前方気門や呼吸角の形態によって, 成虫では複眼の被毛やその模様, 更には翅脈などによって種の識別が容易になった。

\section{4 北海道勇払原野弁天沼周辺におけるアブ類の採集記録}

○塩沢 鉄也・佐々木 均（酪農大·環境昆虫）

Tabanid flies captured at Benten-numa lake in Yuhutsu, Hokkaido

Shiozawa, T., Sasaki, H.

北海道苫小牧市の苫東地区に広がる, 勇払原野弁天沼周辺において 2003年7月上旬から9月中 旬までの期間，ドライアイス $1 \mathrm{~kg}$ を補助的誘引源としたNZIトラップを用いて吸血性アブ類の 捕獲調査を行った。その結果, ニッポンシロフアブが 909 個体捕獲され最優占種となり，ホ ルバートアブ493個体，フタスジアブ254個体，キバラアブ124個体，キンメアブ94個体，ア カアブ75個体, Atylotus sp.42個体と続く5属12種2,029個体採集を得た.Atylotus sp.は稲岡 （1993）が仮称ユウフツキイロアブとした種のようにみられるが，現時点では未同定種として 扱うのが妥当と考えられる。 今後所属を決定していきたい. 